\title{
AKSJOLOGIA UNIWERSYTETÓW I AKSJOLOGIA SNS. WYBRANE ASPEKTY FUNKCJONOWANIA AKADEMII W MEDIACH SPOŁECZNOŚCIOWYCH
}

\author{
Abstract \\ AXIOLOGY OF UNIVERSITIES AND SNS. SELECTED ASPECTS \\ OF THE FUNCTIONING OF ACADEMIA IN SOCIAL MEDIA
}

Phenomena such as globalization, marketization of the public sector institutions, and the massification of higher education have brought about the necessity to reshape academia and its modus operandi. The progressive digitization of society has caused that new technologies and their tools, thus the Internet and the social networking, have become an important element of the functioning of the university. This has led to the development of a completely new range of issues, such as the democratization of the universities, innovative ways of pursuing their learning mission, digital exclusion, and the weakening of the archetypal master-student relationship. The aim of this article is to present selected aspects of the functioning of universities in social media in critical terms, focusing on the axiology of the topics discussed.

Key words: social media, SNS, university, axiology

\section{Wstęp}

Można zauważyć, że na przestrzeni ostatnich dziesięcioleci zaczęła się dokonywać zmiana w uniwersyteckiej materii. Zdaniem niektórych badaczy Humboldtowska formuła akademii wyczerpuje się i ulega dezaktualizacji, nie przystając już do zmienionego, kapitalistycznego i ponowoczesnego otoczenia ${ }^{1}$. Zjawiska takie jak

${ }_{1}$ Zob. M. Kwiek, Transformacje uniwersytetu. Zmiany instytucjonalne i ewolucje polityki edukacyjnej w Europie, Wydawnictwo Naukowe UAM, Poznań 2010; J.G. Wissema, Uniwersytet trzeciej generacji. Uczelnia XXI wieku, Wydawnictwo Zante, Zębice 2009. 
globalizacja, europeizacja, umasowienie szkolnictwa wyższego, urynkowienie sektora publicznego czy pogłębiająca się cyfryzacja i usieciowienie społeczne wymuszają na uniwersytetach transformację o charakterze paradygmatycznym² ${ }^{2}$, która przewiduje przemianę $\mathrm{z}$ akademickiej wieży $\mathrm{z}$ kości słoniowej w uczelnię przedsiębiorczą. Jak wskazuje Krzysztof Leja, „uniwersytet współczesny z uwagi na złożoność zachowań i oczekiwań otoczenia” wyróżniać powinien się „elastycznością celów” i „strategii”, dzięki czemu zostanie „ekwifinalną organizacją, która jest zdolna do osiągania celów różnymi drogami”’3.

Presja otoczenia połączona $\mathrm{z}$ chęcią realizowania partykularnych założeń sprawiły, że portale społecznościowe znalazły się w obrębie zainteresowania akademii. Dzięki funkcjom oferowanym przez Social Networking Service (SNS) serwisy tego typu stały się nieodłącznym elementem codzienności ich użytkowników, będąc tym samym „nieformalnymi i efemerycznymi przejawami życia społecznego" ${ }^{4}$. Potencjał tkwiący w portalach społecznościowych z powodzeniem zaczął być wykorzystywany także przez wyższe uczelnie. Obecność uniwersytetów w social media, mimo niewątpliwych korzyści w postaci np. promocji oferty uczelni czy zapewnienia nowych narzędzi do realizowania misji kształceniowej, może nieść za sobą wiele zagrożeń. Wspomnieć należy przede wszystkim o osłabieniu charakterystycznej dla akademii relacji mistrz-uczeń, a także wykluczeniu cyfrowym niektórych wykładowców.

Interesującym aspektem funkcjonowania uczelni w granicach SNS jest niewątpliwy konflikt na poziomie aksjologii omawianych podmiotów. Uniwersytet hołdujący wartościom najwyższym, a więc prawdzie, pięknie i dobru, w przestrzeni internetowej funkcjonuje w miejscu, które cechują mitologizacja i aksjologiczna fasadowość ${ }^{5}$ Należy podać w wątpliwość udział uniwersytetów w działaniach organizacji, której aksjologia w znacznym stopniu pozostaje odmienna od wartości pielęgnowanych przez akademie. Celem tego artykułu jest opisanie systemu wartości zarówno uniwersytetów, jak i SNS, zarysowanie presji wymuszających transformację akademii, a także przedstawienie wybranych aspektów funkcjonowania uniwersytetów w mediach społecznościowych w ujęciu krytycznym.

2 A. Kobylarek, Uniwersytet wobec konieczności paradygmatycznej zmiany, Agencja Wydawnicza ARGI, Wrocław 2016.

${ }^{3}$ K. Leja, Uniwersytet na rozdrożu, „Studia i Prace Kolegium Zarządzania i Finansów. Szkoła Główna Handlowa” 2017, nr 155, s. 19.

${ }^{4}$ J. van Dijck, The Culture of Connectivity: A Critical History of Social Media, Oxford University Press, Oxford 2013, s. 6.

${ }^{5} \mathrm{~J}$. Kreft, Za fasada społeczności. Elementy zarządzania nowymi mediami, Wydawnictwo Uniwersytetu Jagiellońskiego, Kraków 2015. 


\section{Aksjologia uniwersytetu}

Uniwersytet jako instytucja wyrastająca z idei Akademii Platońskiej i Liceum Arystotelejskiego ${ }^{6}$ oraz będąca jednym z trzech filarów wieków średnich (studium) ${ }^{7}$, na przestrzeni wieków wykształciła sui generis system wartości oraz szczególnego typu tożsamość. Dla Jerzego Woźnickiego akademię w funkcjonowaniu wyróżnia nie tylko realizowanie misji czy respektowanie służby publicznej, lecz także nieustanne odwoływanie się do „wielowiekowych uniwersalnych tradycji akademickich”. Wartości stały się zatem immanentnym elementem akademii, fundamentem jej autorytetu oraz budulcem doniosłych kulturotwórczych i kształceniowych funkcji.

Za Władysławem Stróżewskim należy uznać, że akademicki etos i system aksjologiczny tworzą: prawda, dobro i piękno9. Wartości te są ściśle ze sobą zespolone i wynikają z siebie, gdyż „poznanie prawdy jest niezbędnym warunkiem czynienia dobra. Piękno zaś, zgodnie z ideami starożytnych, może być uznane za estetyczny wyraz dobra" 10 . Etos akademii przywołujący elementarne wartości formułuje sposób, w jaki organizacja ta powinna być postrzegana, stanowiąc tym samym aksjologiczny drogowskaz dla jej członków. Poruszane zagadnienia zawierają się natomiast $\mathrm{w}$ uniwersyteckim dostojeństwie, które wypływa nie tylko $\mathrm{z}$ „sędziwego wieku i chlubnych tradycji uczelni”, lecz także z „samej idei Uniwersytetu, która się z biegiem czasu ustaliła i która wyznacza mu funkcję, jaką on ma pełnić w życiu zbiorowym współczesnej ludzkości”" ${ }^{11}$. W tym znaczeniu prymarnym celem akademii jest „Zdobywanie prawd i prawdopodobieństw naukowych oraz krzewienie umiejętności ich dochodzenia"12. Zdaniem Franciszka Ziejki owo dostojeństwo uniwersytetu jest dziś zagrożone. Wynika to z kryzysu świata akademickiego, w którym wartości wyższe ustępują użyteczności, dochodowości i realizowaniu partykularnych celów ${ }^{13}$.

Pielęgnowanie dostojeństwa uniwersytetów powinno dokonywać się przede wszystkim przez członków akademickiej wspólnoty, którzy budują „w każdej epoce, także i dzisiaj, prawdziwy autorytet moralny uniwersytetu" ${ }^{\prime 4}$. Za działania

${ }^{6}$ J.G. Wissema, Uniwersytet trzeciej generacji..., dz. cyt., s. 16.

7 K. Leja, Zarzadzanie uczelnia: koncepcje i współczesne wyzwania, Wolters Kluwer Polska, Warszawa 2013, s. 30.

${ }^{8}$ J. Woźnicki, Uczelnie akademickie jako instytucje życia publicznego, Fundacja Rektorów Polskich, Warszawa 2007, s. 19.

9 W. Stróżewski, W kręgu wartości, Wydawnictwo Znak, Kraków 1992.

${ }^{10}$ K.Z. Sowa, Społeczne funkcje szkolnictwa i elitotwórcza rola uniwersytetu. Uwagi socjologa, [w:] K. Leja (red.), Społeczna odpowiedzialność uczelni, Wydział Zarządzania i Ekonomii Politechniki Gdańskiej i Instytutu Społeczeństwa Wiedzy, Gdańsk 2008, s. 40.

${ }^{11}$ K. Twardowski, O dostojeństwie Uniwersytetu, Uniwersytet Poznański, Poznań 1933.

12 Tamże.

${ }^{13}$ F. Ziejka, Czy można dziś jeszcze mówić o dostojeństwie uniwersytetu?, [w:] P. Sztompka, K. Matuszek (red.), Idea uniwersytetu. Reaktywacja, Wydawnictwo Uniwersytetu Jagiellońskiego, Kraków 2014.

14 Tamże, s. 52. 
o charakterze wspomagającym można uznać zapisy zawarte $\mathrm{w}$ wewnętrznych i powszechnie obowiązujących dokumentach oraz aktach prawnych. W kontekście akademickich wartości niezwykle ważny i aktualny pozostaje chociażby Kodeks dobrych praktyk w szkołach wyższych, przyjęty przez Zgromadzenie Plenarne Konferencji Rektorów Akademickich Szkół Polskich w 2007 roku $^{15}$. Mimo iż rzeczony Kodeks nie ma charakteru obowiązującego, stanowi zbiór dyrektyw oraz sugestii postępowania, które wyznaczają kierunek i sposób osiągnięcia dobrej pragmatyki służbowej. Dokument ten sformułowany został „w trosce o pielęgnację i upowszechnianie [...] dobrych obyczajów w nauce, odzwierciedlających wielowiekową tradycję życia akademickiego", które są „spoiwem formalnych i nieformalnych zaleceń oraz zasad [...] kształtowania i utrzymania etosu" akademii ${ }^{16}$. Z perspektywy omawianego Kodeksu podstawą funkcjonowania uniwersytetów jest prawda, osiąganie jej i kształcenie młodych pokoleń w jej duchu. Realizacja założeń społecznych oraz dydaktyczno-wychowawczych powiązana jest natomiast $\mathrm{z}$ imperatywem wartości humanistycznych, przedsiębiorczości i otwartości, współpracy z innymi podmiotami społecznymi czy poszanowania tradycji kraju i regionu oraz „podejmowania we właściwy sobie sposób wyzwań zmieniającego się świata" ${ }^{17}$. Respektowanie wymienionych wartości przez członków organizacji nie tylko kształtuje „szczególną kulturę instytucjonalną” uniwersytetu, lecz także wpływa na siłę jej oddziaływania na otoczenie ${ }^{18}$.

Do uporządkowania systemu aksjologicznego akademii przydatna okazać się może także jej misja. Wyraża ona bowiem „posłannictwo organizacji i definiuje jej cel, dla którego została powołana, oraz określa rolę, jaką pełni w danym środowisku"19. Dla Kazimierza Sowy uniwersytecka misja konstytuuje się dzięki trzem niezbywalnym elementom: badaniom, nauczaniu i służbie publicznej ${ }^{20}$. Połączenie tych przymiotów, a więc integralność dydaktyki i działalności badawczej sprawia, że uniwersytet uzyskuje swój wyjątkowy charakter, „jest równocześnie szkołą, warsztatem naukowym, a także kuźnią idei i wartości społecznych oraz najwyższej jakości kadr"21. Znaczenie akademickiej misji dostrzega również polski ustawodawca uznający, iż „uczelnie, pełniąc misję odkrywania i przekazywania prawdy poprzez prowadzenie badań i kształcenie studentów, stanowią integralną cześć narodowego systemu edukacji i nauki”22.

${ }^{15}$ Fundacja Rektorów Polskich i Konferencja Rektorów Akademickich Szkół Polskich, Dobre praktyki w szkołach wyższych: kodeks opracowany przez Fundację Rektorów Polskich, uchwalony przez Zgromadzenie Plenarne Konferencji Rektorów Akademickich Szkół Polskich 26 kwietnia 2007, Fundacja dla Uniwersytetu Jagiellońskiego, Kraków 2007.

16 Tamże, s. 5.

17 Tamże, s. 6.

18 Tamże.

19 S. Marek, Elementy nauki o przedsiębiorstwie, Economicus, Warszawa 2008, s. 20.

${ }^{20}$ K.Z. Sowa, Społeczne funkcje szkolnictwa..., dz. cyt., s. 40.

21 Tamże.

${ }^{22}$ Art. 4 ust 3. Ustawy z dnia 27 lipca 2005 r. - Prawo o szkolnictwie wyższym (Dz.U. 2017 nr 2183, t.j. z późn. zm.). 
Jak zauważa jednak Ewa Chmielecka, misja akademii w coraz mniejszym stopniu utożsamiana jest $\mathrm{z}$ jej tradycyjną aksjologią, w coraz większym zaś ze strategią, realizacją celów czy określonymi standardami akredytacji ${ }^{23}$. Tezę tę potwierdza m.in. pogląd Magdaleny Ławickiej, dla której „misja szkolnictwa wyższego dotyczy realizacji zadań o długoterminowej perspektywie oddziaływania, co wymaga od uczelni wyższych prowadzenia wielu działań zgodnych z potrzebami otoczenia, w którym funkcjonuje" ${ }^{24}$. Takie postrzeganie misji akademii zwraca uwagę na przekształcenia, którym poddawane są współczesne uniwersytety. Proces ten powinien odbywać się jednak w zgodzie z tradycyjnymi wartościami uczelni, gdyż bez nich działalność poznawcza „prowadzona z innych pobudek niż samo dążenie do dobra i prawdy” może być „społecznie bezużyteczna, a nawet niebezpieczna”25.

\section{Konieczność transformacji akademii}

Za Piotrem Sztompką należy przyjąć, że uniwersytet jest instytucją szczególną. „Gdy powstawał w średniowieczu, odróżniał się od razu od dworu monarszego, Kościoła, [...] a później przez wieki był istotnie inny od urzędów państwowych, armii, przedsiębiorstw, innych rodzajów szkół" ${ }^{26}$. Jego differentia specifica zasadzała się na apoteozie rozumu, szczególnej misji kształceniowej w integralny sposób połączonej z własnymi badaniami i poszukiwaniu prawdy nawet wtedy, gdy ta jawiła się jako „całkowicie bezużyteczna"27. Rozpatrywanie tych zagadnień w czasie przeszłym nie jest jednak przypadkowe. Zdaniem Marka Kwieka „wyjątkowość uniwersytetu jako instytucji społecznej w dominującym w Europie dyskursie naukowym, politycznym i eksperckim wyraźnie zanika”28. Stopniowej dezaktualizacji ulega także „okres ochronny tej instytucji”, który był skutkiem „kilkudziesięcioletniej zbieżności interesów państwa narodowego [...] i interesów instytucji edukacyjnych"29.

Przyczynkiem dla uniwersyteckiej zmiany jest przemiana otoczenia, w której instytucja ta funkcjonuje - mowa tu przede wszystkim o presjach zewnętrznych, „których najlepszym przykładem jest globalizacja i europeizacja”, oraz presjach wewnętrznych, „takich jak na przykład zmieniająca się demografia i starzenie się

${ }^{23}$ E. Chmielecka, Kilka uwag o etosie i kodeksach akademickich oraz o odpowiedzialności uczel$n i$, [w:] K. Leja (red.), Społeczna odpowiedzialność uczelni, dz. cyt.

${ }_{24}$ M. Ławicka, Społeczna odpowiedzialność uczelni wyższej w Polsce, „Zeszyty Naukowe Wyższej Szkoły Humanitas. Zarządzanie” 2016, nr 3, s. 209, https://doi.org/10.5604/18998658.1228272 (dostęp: 3.07.2018).

${ }_{25}$ K.Z. Sowa, Społeczne funkcje szkolnictwa..., dz. cyt., s. 40.

${ }^{26}$ P. Sztompka, Uniwersytet współczesny: zderzenie dwóch kultur, „Nauka” 2014, nr 1, s. 8, http:// yadda.icm.edu.pl/yadda/element/bwmeta1.element.pan-n-yid-2014-iid-1-art-000000000001 (dostęp: 3.07.2018).

27 Tamże.

${ }^{28}$ M. Kwiek, Transformacje uniwersytetu..., dz. cyt., s. 29.

29 Tamże. 
większości europejskich społeczeństw, rosnące i coraz trudniejsze do zaspokojenia wymagania finansowe klasycznych państw dobrobytu czy postpatriarchalne wzorce rodziny i związane z nimi zmiany struktury rynków pracy"30. Nie bez znaczenia pozostaje również obecna kondycja całego systemu edukacji. Umasowienie szkolnictwa wyższego połączone $\mathrm{z}$ wzmożoną konkurencją na rynku usług edukacyjnych sprawiają, że uniwersytety $w$ coraz większym stopniu zainteresowane muszą być narzędziami, które pozwolą im wyróżnić się na rynku i uzyskać znaczną przewagę konkurencyjną.

Z perspektywy uniwersytetów publicznych najważniejszy proces stanowi urynkowienie (marketyzacja) sektora publicznego. W myśl założeń Public Governance jednostki działające w ramach tego sektora wyróżniać powinny: „Zaangażowanie interesariuszy, jawność i przejrzystość, równość i brak dyskryminacji [...], etyka w służbie publicznej, odpowiedzialność (accountability) oraz dążenie do zrównoważonego rozwoju (sustainability)" ${ }^{31}$. Proces marketyzacji ma natomiast prowadzić do „korzystnych zmian $\mathrm{w}$ realizacji potrzeb zaspokajanych publicznie $\mathrm{w}$ wyniku oferowanych usług” ${ }^{32}$. Jego celem jest ponadto „uzdrowienie” owego sektora, zaś "dopuszczenie konkurencji jako elementu bazowego" sprawia, że jednostki publiczne cechować musi wysoka jakość świadczonych usług, efektywność oraz konieczność wyróżnienia się na rynku, pozostania „widocznym” dla społeczeństwa ${ }^{33}$. Dla uniwersytetów oznaczać to może nie tylko przymus realizowania nowej gamy zadań czy redefinicję stawianych celów, lecz także zmianę na poziomie instytucjonalnym i transformację w kierunku uniwersytetu „trzeciej generacji”, „przedsiębiorczego”, „posttradycyjnego” czy „2.0”. Przewartościowanie podstawowych założeń akademii pod kątem ekonomicznym $\mathrm{z}$ jednej strony pozwoliłoby na podołanie dezyderatom współczesności, z drugiej zaś zarówno dyktat efektywności, jak i korporacyjną ideę uczelni przyrównać można do „wirusa”, który w znacznym stopniu przyczynia się do erozji tradycyjnego modelu akademii ${ }^{34}$.

Jednym $\mathrm{z}$ fundamentalnych czynników wymuszających zmianę na uniwersytetach jest postępująca cyfryzacja społeczeństwa oraz jego usieciowienie. Wagę rewolucji cyfrowej przyrównać można jedynie do tej na miarę wynalezienia druku przez Gutenberga ${ }^{35}-\mathrm{z}$ tego powodu nowe technologie oraz ich możliwości powinny znaleźć się w ścisłym kręgu zainteresowań akademii. Zarządzanie uniwersytetami, które wykorzystuje postęp w technologii informatycznej, tj. komputery, telekomunikację oraz

30 Tamże, s. 20-21.

${ }^{31}$ J. Hausner, Zarządzanie publiczne, Wydawnictwo Naukowe Scholar, Warszawa 2008, s. 24.

32 R. Folga, Perspektywy $i$ wyzwania marketingu $w$ administracji publicznej $w$ Polsce, „Studia Ekonomiczne. Uniwersytet Ekonomiczny w Katowicach” 2014, nr 194, s. 86.

${ }_{33}$ P. Szeremet, Zastosowanie marketingu społecznego $w$ realizacji zadań własnych administracji samorządu gminnego, „Zeszyty Naukowe Uniwersytetu Szczecińskiego. Problemy Zarządzania, Finansów i Marketingu" 2012, nr 27, s. 349.

34 P. Sztompka, Uniwersytet wspótczesny..., dz. cyt., s. 9.

${ }^{35}$ T. Goban-Klas, Uniwersytet $w$ kontekście nowych mediów i technologii informacyjnych, [w:] P. Sztompka, K. Matuszek (red.), Idea uniwersytetu..., dz. cyt., s. 308. 
sieć, pozwala na tworzenie wspólnot zainteresowanych wymianą doświadczeń, a także na rozwój badań oraz działalności edukacyjnej ${ }^{36}$.

Zdaniem Aleksandra Kobylarka akademie powinny monitorować i „synchronizować” swoje działania i swój rozwój z rozwojem całego społeczeństwa ${ }^{37}$. Jest to warunek konieczny, by uniwersytety pozostały integralną i autorytatywną częścią otaczającego ich świata. Mówi o tym również Roman Batko, wskazując, iż jedyną szansą dla ponowoczesnych uniwersytetów jest odwołanie się do charakterystycznej dla nich roli przywódczej, którą wypełniać powinny w płynnych, niepewnych czasach $^{38}$. Przyjęcie owej roli musi być jednak, przynajmniej częściowo, związane $\mathrm{z}$ implementacją niektórych rozwiązań technologicznych. Bezsprzeczny pozostaje bowiem fakt, że „obecnie media są splecione $z$ działaniem wszelkich innych instytucji, a zarazem ich logika w znacznej mierze określa działanie tychże instytucji, a w mniejszym stopniu pozostaje określona przez ich logikę" ${ }^{39}$. Z tego powodu „o mediatyzacji nie mogą więc już zapomnieć żadne instytucje, nie wyłączając najstarszych i renomowanych uniwersytetów" ${ }^{40}$. Zdaniem Tomasza Gobana-Klasa akademiccy „barbarzyńcy u bram” (studenci) od dawna są „już w środku, a ich orężem są tablety i smartfony, środkiem komunikacji, promocji, koordynacji Facebook” ${ }^{41}$. Teza ta wskazuje nie tylko na „spóźnienie” uniwersytetów względem nowych technologii, lecz także rysuje nowe wyzwania stojące przed uczelniami, takie jak komunikacja z „cyfrowymi” studentami lub ich edukacja.

Bronisław Siemieniecki podkreśla, że z perspektywy akademickiej nowe technologie posiadają niezwykły potencjał, gdyż dają możliwość „utrzymania wiodącej roli uczelni wyższych w kreowaniu wiedzy i jej dostarczaniu do społeczeństwa"42. W myśl tej tezy realizacja podstawowych zadań uczelni przynajmniej w częściowym stopniu musiałaby być przeniesiona do sieci internetowej. Dla autora jest to jedyny sposób, by pogodzić nowe oczekiwania społeczne i rezultaty działań współczesnych uniwersytetów ${ }^{43}$.

Jako że uniwersytet „idealnie wkomponuje się w ideę społeczeństwa sieciowego”, a związek tych dwóch materii można uznać za „ewidentny”" ${ }^{44}$ wspomnieć należy

${ }^{36}$ A. Krajewska, Wyzwania wobec uniwersytetu XXI wieku, [w:] A. Ładyżyński, J. Raińczuk (red.), Uniwersytet - między tradycją a wyzwaniami współczesności, Wydawnictwo Impuls, Kraków 2003 , s. $70-72$.

${ }^{37}$ A. Kobylarek, Uniwersytet w komunikacyjnej sieci, [w:] A. Kobylarek, J. Semków (red.), Edukacja uniwersytecka w warunkach zmiany kulturowej, Oficyna Wydawnicza Atut, Wrocław 2008, s. 79.

${ }^{38}$ R. Batko, Liquid University, [w:] J. Kociatkiewicz, M. Kostera (red.), Liquid Organization: Zygmunt Bauman and Organization Theory, Routledge, London-New York 2014, s. 117.

${ }^{39}$ T. Goban-Klas, Uniwersytet w kontekście nowych mediów..., dz. cyt., s. 306.

40 Tamże.

${ }^{41}$ Tamże.

${ }^{42}$ B. Siemieniecki, Uniwersytet w świecie mediów i technologii informacyjnej, [w:] P. Sztompka, K. Matuszek (red.), Idea uniwersytetu..., dz. cyt., s. 322.

43 Tamże.

${ }^{44}$ A. Kobylarek, Uniwersytet w komunikacyjnej sieci..., dz. cyt., s. 92. 
również o wytworzeniu się nowego typu uniwersyteckich funkcji i zadań, które związane są z sieciami komputerowymi sensu stricto. Dla Aleksandra Kobylarka jest to przede wszystkim potrzeba nadawania przez akademię wiarygodności danemu wycinkowi rzeczywistości cyfrowej, budowania oraz podtrzymywania wewnętrznych sieci komunikacyjnych umożliwiających porozumiewanie się i przepływ informacji czy konieczność implementowania i rozwijania idei edukacji sieciowej ${ }^{45}$.

\section{Aksjologia mediów społecznościowych}

SNS (Social Networking Service) powstał wskutek przeobrażenia Web 1.0 w środowisko Web 2.0. Działanie Web 1.0, stworzonego na gruncie systemu World Wide Web, w początkowej fazie odbywało się „na podstawie modelu klient-serwer w ten sposób, że przeglądarki [...] wysyłają żądania danych do serwera, a ten w odpowiedzi przesyła dokumenty HTML" ${ }^{46}$. Taki sposób wymiany informacji cechował się brakiem intuicyjności i ergonomiczności oraz jednokierunkową komunikacją. Zarządzać treściami mogły wyłącznie osoby posiadające specjalistyczną wiedzę, określone kwalifikacje i zasoby - ich odbiorcy zajmowali natomiast postawę bierną ${ }^{47}$. Utworzenie Web 2.0 sprawiło, że pasywni użytkownicy zostali „aktywnymi twórcami wpływającymi na kształt tworzonej sieci”, zaś nadawcy zaczęli „pełnić bardziej funkcję inicjatorów pozostawiających dalszy rozwój serwisu swoim odbiorcom" ${ }^{48}$. Interaktywność tego modelu korzystania z Internetu pozwoliła na personalizację treści i indywidualizację oferty, sprzyjając tym samym wymianie i łączeniu informacji ${ }^{49}$.

Portale społecznościowe zdefiniować można jako grupę aplikacji internetowych powstałych na „ideologicznych i technologicznych podstawach Web 2.0, które umożliwiają tworzenie i wymianę treści generowanych przez użytkowników" ${ }^{50}$. Pozwalają one między innymi na kreowanie osobistych profili, a także na nawiązywanie relacji i komunikację między użytkownikami. Zdaniem Christiana Fuchsa ideologia Web 2.0 ma trojaki charakter: neoliberalny, polityczny oraz marketingowy ${ }^{51}$.

45 Tamże, s. 81-88.

46 R. Maciąg, Pragmatyka Internetu. Web 2.0 jako środowisko, Wydawnictwo Uniwersytetu Jagiellońskiego, Kraków 2013, s. 20.

47 Ł. Sarowski, Od Internetu Web 1.0 do Internetu Web 4.0 - ewolucja form przestrzeni komunikacyjnych w globalnej sieci, „Rozprawy Społeczne” 2017, t. 11, nr 1, s. 34.

48 Tamże.

49 Tamże.

50 A.M. Kaplan, M. Haenlein, Users of the World, Unite! The Challenges and Opportunities of Social Media, „Business Horizons” 2010, t. 53, nr 1, s. 61.

51 C. Fuchs, Social Software and Web 2.0: Their Sociological Foundations and Implications, [w:] S. Murugesan (red.), Handbook of Research on Web 2.0, 3.0, and X.0: Technologies, Business and Social Applications, IGI Global, Hershey-New York 2010, s. 768, http://fuchs.uti.at/wp-content/uploads/2009/12/Web2.pdf (dostęp: 3.07.2018). 
Neoliberalny, ponieważ portale społecznościowe oparte są na elementarnych liberalnych wartościach, tj. wolności wyboru i aktywności, natomiast ich użytkownicy określani są jako osoby wolne od zewnętrznej kontroli ${ }^{52}$. Ideologia Web $2.0 \mathrm{ma}$ charakter polityczny, gdyż z jednej strony tworzy nowy rodzaj sfery publicznej, która pozwala na swobodne wyrażanie opinii. $Z$ drugiej zaś - owa internetowa sfera publiczna przywłaszczona może być przez polityków czy partie polityczne, przez co głos pojedynczych użytkowników będzie marginalizowany i niesłyszalny, a oni sami, mimo iluzorycznego wrażenia, że mogą coś zmienić, w rzeczywistości nie posiadają realnego wpływu na politykę ${ }^{53}$.

Ideologia marketingowa wiąże się natomiast z kryzysem ekonomicznym dotcom bubble, który nastąpił w 2000 roku i doprowadził do przekształcenia Web 1.0 w środowisko 2.0. Pęknięcie bańki spekulacyjnej dotyczącej firm internetowych notowanych na NASDAQ, a więc pierwsze poważne załamanie nowej gospodarki sprawiło, iż zrodziła się potrzeba, by „opowiedzieć” Internet na nowo i stworzyć dla niego szczególnego typu strategię marketingową, która skłoni inwestorów do ponownego zaangażowania finansowego ${ }^{54}$. Zdaniem danah boyd „dla przedsiębiorców i geeków obserwujących, jak Internet przekształca się w dot-com bańkę i ostatecznie staje w płomieniach, Web 2.0 i jego pierwsza oferta - media społecznościowe - dały szansę na nowy początek" ${ }^{35}$.

Ideologiczne i aksjologiczne podwaliny funkcjonowania SNS immanentnie związane się więc $\mathrm{z}$ sui generis mitami i to w nich się konkludują. Mity w organizacjach mają bowiem „szczególną moc”, poruszają "jakieś głębokie kulturowe struny”, sprawiają, że „kryteria realistycznej prawdy nie są istotne - mit opowiada o rzeczach, które "nie wydarzyły się naprawdę" w świecie zewnętrznym, lecz są prawdziwe dla ludzi w wymiarze wewnętrznym, duchowym"56. Monika Kostera przyjmuje, że mity w organizacjach pełnią szczególną funkcję, gdyż „dają poczucie przynależności do czegoś więcej niż dana organizacja, jednocześnie nie wyrywając z jej struktur”, „wywołują szacunek wobec szerszego kontekstu bez negowania granic organizacji”, „legitymizują porządek społeczny organizacji” oraz „prowadzą przez etapy życia organizacyjnego" ${ }^{57}$. Z tego powodu z powodzeniem wykorzystuje się je zarówno w opisie uniwersum Web 2.0, jak i jego sztandarowego produktu portali społecznościowych ${ }^{58}$.

52 Tamże.

53 Tamże.

${ }_{54}$ Tamże, s. 767.

55 d. boyd, Social Media: A Phenomenon to be Analyzed, „Social Media + Society” 2015, t. 1, nr 1, s. 1, https://doi.org/10.1177/2056305115580148 (dostęp: 3.07.2018).

${ }_{56}$ M. Kostera, M. Śliwa, Zarządzanie w XXI wieku. Jakość, twórczość, kultura, Wolters Kluwer Polska, Warszawa 2012, s. 193.

${ }_{57}$ M. Kostera, Archetypy, opowieści archetypiczne i metafory, [w:] M. Kostera, B. Glinka (red.), Nowe kierunki w organizacji i zarzadzaniu. Organizacje, konteksty, procesy zarzadzania, Wolters Kluwer Polska, Warszawa 2012, s. 164.

${ }^{58}$ J. Kreft, Za fasadą społeczności..., dz. cyt. 
Zdaniem Jana Krefta do najpowszechniejszych mitów nowych mediów zaliczyć można mit współtworzenia treści medialnych i uczestnictwa oraz mit „darmowych obiadów”. Pierwszy odnosi się do założenia, że internetowe audytorium „mające stać się na masową skalę zbiorami aktywnych, twórczych użytkowników” jest jedynie niewielką, „zaradną awangardą” osób partycypujących w Web $2.0^{59}$. Większość internautów pozostaje natomiast bierna, kultywuje tym samym tradycyjne postawy konsumenckie i nie wykorzystuje w pełni możliwości, które oferowane są przez SNS ${ }^{60}$. Mit „darmowych obiadów” zasadza się na całkowitym utowarowieniu aktywności i prywatności użytkowników przez medialne konglomeraty, które w zamian zapewniają im „darmowe” aplikacje i „darmowy” dostęp do nich ${ }^{61}$. Prowadzi to do pogłębienia licznych patologii, takich jak dehumanizacja użytkowników, inwigilacja czy brak transparentności organizacji lub świadczonych przez nie usług.

Mając w pamięci wymieniane przez Fuchsa ideologie ekonomiczne, polityczne i marketingowe, a także biorąc pod uwagę problem mitologizowania organizacji nowomedialnych, należy przyjąć, że aksjologia będąca fundamentem social media jest niczym innym jak pewnego rodzaju retoryką uprawianą w celu realizowania określonych założeń i celów. Retoryka społeczności, podobnie jak mity SNS, „opowiada” i wartościuje portale społecznościowe, opisując „rynkowe nowe media jako świat »wspólnot «, »demokracji «, "pasji współtworzenia« i "zaufania «"62. „Przez nadawanie takich etykiet, jak choćby »media społecznościowe« czy "przestrzeń przyjaciół «, konstruowany jest problem społeczny, narzucona jest narracja” ${ }^{63}$, która w fałszywy sposób opisuje zarówno nowomedialne konglomeraty, jak i ich działania. Tworzona jest więc „społecznościowa fasada”, która korygowana jest tak, aby „spełniała oczekiwania użytkowników i oczekiwania te kreowała, utwierdzając ich w trafności wyborów" ${ }^{4}$. Za fasadą tą kryje się jednak zwykły biznes i konieczność realizowania podstawowych ekonomiczno-finansowych celów: „wzrostu bogactwa akcjonariuszy, maksymalizacji zysku i zwiększenia udziału w rynku”"65. Przysłania ona również zagrożenia SNS, takie jak dehumanizacja i inwigilacja użytkowników, wykorzystywanie ich darmowej pracy, a także przywłaszczenie i monetyzowanie wartości oraz danych ${ }^{66}$.

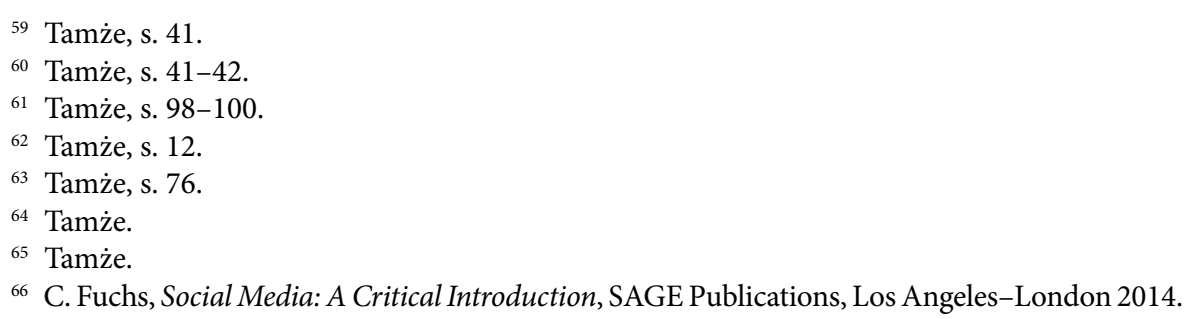




\section{Aktywność uniwersytetów w portalach społecznościowych}

Uniwersytety nie mogą obecnie ignorować mediów społecznościowych ani ich siły. Postępujące urynkowienie sektora publicznego sprawia, że uczelnie w coraz większym stopniu muszą być zorientowane na realizowanie trzeciej misji, czyli współdziałania $z$ otoczeniem ${ }^{67}$. By wypełnianie jej mogło przebiegać w sposób efektywny, akademie powinny dostosować swój sposób porozumiewania się z otoczeniem tak, aby „sprzyjać budowaniu modelowych relacji”" ${ }^{68}$. $Z$ tego powodu proces komunikacji z otoczeniem przynajmniej w częściowy sposób przeniesiony został do cyberświata, do portali społecznościowych. Na obecność akademii w social media wpływa wiele czynników.

Po pierwsze, za taki uznać należy potrzebę komunikacji z członkami organizacji, studentami i potencjalnymi kandydatami. Dla pokolenia, które „dorastało w cieniu monitora” i dla którego „myszka i klawiatura stanowiły od dziecka rodzaj zabawki” ${ }^{69}$, portale społecznościowe stają się naturalnym „miejscem spotkania”, także z organizacjami. Uniwersytety powinny więc zaznaczać swą obecność w portalach społecznościowych, co nie tylko ułatwi procesy komunikacyjne na poziomie akademia-otoczenie, lecz także wpłynie na lepszą realizację oczekiwań i potrzeb (publiczne instytucje szkolnictwa wyższego powinny być bardziej otwarte, bliższe, ich działania cechować muszą się dużą innowacyjnością, kreatywnością, ale też transparentnością).

Po drugie, portale społecznościowe stają się narzędziem wykorzystywanym do wypełniania uniwersyteckiej misji kształceniowej. Coraz więcej nauczycieli decyduje się na tworzenie specjalnych grup w ramach przedmiotu, które pozwalają m.in. na „monitorowanie frekwencji i aktualnych ocen poprzez regularne zamieszczanie odpowiednich tabel”, publikowanie „informacji o planowanych kolokwiach, egzaminach, zakresie materiału do opanowania czy przygotowania" oraz zamieszczanie lektur (grupa na portalu społecznościowym jest pewnego rodzaju „repozytorium cyfrowym, gdzie każdy ma dostęp do materiałów w dowolnym momencie i miejscu" $)^{70}$. Portale społecznościowe jawią się więc jako narzędzie szczególnie atrakcyjne zarówno dla nauczycieli, jak i studentów, które umożliwia edukowanie i efektywne organizowanie zajęć.

${ }^{67}$ W. Zuziak, O powinnościach uniwersytetu, [w:] P. Sztompka, K. Matuszek (red.), Idea uniwersytetu..., dz. cyt., s. 56 .

${ }_{68}$ T. Aleksandrowicz, Relacje uniwersytetu i społeczności lokalnych w mediach społecznościowych. Analiza stron profilowych $w$ serwisie Facebook dla pięciu największych polskich uniwersytetów w 2014 roku, [w:] T. Wawak, J.F. Jacko (red.), W poszukiwaniu uniwersytetu idealnego, Wydawnictwo Uniwersytetu Jagiellońskiego, Kraków 2016, s. 157.

69 A. Kobylarek, Uniwersytet wobec konieczności..., dz. cyt., s. 37.

${ }^{70} \mathrm{~K}$. Knoch, Zastosowanie Facebooka w pracy ze studentami. Refleksje dotyczace wykorzystania serwisu w praktyce dydaktycznej, „Zarządzanie Mediami” 2017, t. 4, nr 4, s. 274-275, https://doi.org /10.4467/23540214ZM.16.015.6529 (dostęp: 3.07.2018). 
Za ostatni z czynników warunkujących obecność uczelni w mediach społecznościowych można uznać potencjał marketingowy i promocyjny SNS. W warunkach wzmożonej konkurencji na rynku usług edukacyjnych „budowanie reputacji i pozytywnego wizerunku uczelni w oczach potencjalnych klientów, pracodawców i innych interesariuszy” pozostaje „istotnym elementem tworzenia przewagi konkurencyjnej" ${ }^{\prime 1}$. Portale społecznościowe pozwalają na tworzenie mierzalnych i atrakcyjnych cenowo kampanii, które mogą dotrzeć do dużej liczby zainteresowanych odbiorców. Wykorzystywanie przez uczelnie social media do celów marketingowych daje nie tylko możliwość promocji oferty edukacyjnej akademii, lecz także może się przyczyniać do tworzenia i pielęgnowania wizerunku uniwersytetu $\mathrm{w}$ przestrzeni internetowej.

Coraz silniejsza presja, by uniwersytet funkcjonował w mediach społecznościowych, może prowadzić do wytworzenia się zupełnie nowego spektrum wyzwań, z którymi muszą się zmierzyć akademie. Aktywność uczelni w SNS zmniejsza chociażby dystans do archetypicznej wieży z kości słoniowej, czyniąc akademię bliższą, bardziej otwartą i dostępną. Tworzenie grup w ramach przedmiotu oraz funkcjonowanie nauczycieli akademickich w social media wypływać może natomiast na osłabienie relacji mistrz-uczeń. „Nauczyciel - do tej pory oddalony i obcy, łatwo może stać się bliski i ludzki, nie tak pomnikowy; taki, z którym da się porozmawiać o sprawach zwyczajnych, niczym z kolegą z sąsiedztwa"72.

Próba implementowania narzędzi SNS przez nauczycieli akademickich nieznających specyfiki tego środowiska, jego osobliwych mód, szczególnego języka czy typowych zachowań może stwarzać problem w komunikacji ,już na poziomie zwykłych znaków (inny język, symbole, skróty myślowe używane przez pokolenie "urodzone z klawiaturą $\mathrm{W}$ ręku«)"73. Mimo że „wielu profesorów nadrabia braki w opanowaniu nowych technologii własnym sumptem - wielu jednak nie poddaje się presji, uważając, że to oni dyktują warunki i do nich [profesorów] należy się dostosować"74. Postawa ta, choć zrozumiała, nie tylko potęguje wykluczenie cyfrowe pewnej grupy nauczycieli i brak wzajemnego zrozumienia, lecz także może prowadzić do narażenia się na śmieszność, co skutkować będzie całkowitą „klęską pedagogiczną" w oczach milenialsów ${ }^{75}$.

Wypada także zauważyć, że funkcjonowanie uniwersytetów w mediach społecznościowych prowadzi do sprzężenia wartości tych dwóch podmiotów - SNS oraz akademii. Nowomedialne portale oparte na sile społeczności stały się nieznaną dotąd platformą dla urzeczywistniania się uczelni w przestrzeni internetowej, czego dopełnieniem pozostaje jej immanentna, eksponowana i promowana także w SNS aksjologia. Na poziomie teoretycznym konstytutywną wartością dla obu

\footnotetext{
${ }_{71}$ A. Pabian, Marketing szkoły wyższej, Oficyna Wydawnicza ASPRA-JR, Warszawa 2005, s. 106.

72 A. Kobylarek, Uniwersytet wobec konieczności..., dz. cyt., s. 17.

73 Tamże, s. 37.

74 Tamże.

75 Tamże, s. 10.
} 
tych podmiotów jest wolność. W Akademickim kodeksie wartości UJ wolność, a więc jeden z podstawowych filarów uczelnianej aksjologii, określona została jako gwarant dla tworzenia się i obowiązywania w społecznościach wartości etycznych. „Wolność jest warunkiem wyboru wartości, ich poszukiwania i kreacji [...] jest zarazem szansą i źródłem energii dla całej struktury nauki, w której tylko swoboda badań, dyskusji i głoszenia poglądów przynosi korzystne rezultaty, zaś jakiekolwiek jej [swobody] ograniczanie rodzi stagnację i uwiąd twórczej myśli"76. Wolność uniwersytetu prowadzi do ciągłości nauki, stanowiąc tym samym źródło autorytetu zarówno dla akademii, jak i jej pracowników. Portale społecznościowe zapewniają natomiast wolność i dowolność komunikowania, wyrażania poglądów i kreowania siebie. Jak zostało to już wcześniej nakreślone, ich neoliberalna logika zasadza się na elementarnych liberalnych wartościach, takich jak wolność, wybór i aktywność ${ }^{77}$, dzięki czemu SNS sprzyja budowaniu społeczności i organizowaniu się, co odpowiadać może także akademickiemu imperatywowi współpracy (potwierdzeniem tych słów niech będą organizowane obecnie na portalach społecznościowych - sic! - akademickie protesty przeciwko „ustawie 2.0 ”).

Zbieżność owych wartości, jak i cała aksjologia portali społecznościowych są jednak fasadowe. Analiza krytyczna SNS prowadzi bowiem do konkluzji, iż wolność użytkowników mediów społecznościowych to jedynie mit, który w poetycki sposób ukrywa jego prawdziwe oblicze - a więc kategoryczne monetyzowanie użytkowników, udostępnianych przez nich danych i treści, tworzonych przez nich relacji oraz ich prywatności. Uniwersytety, dołączając do portali społecznościowych i prowadząc w ich granicach działania, niejako pośrednio godzą się na fasadowość i lichą moralność SNS. W konsekwencji uniwersytety stworzone jako instytucje w służbie prawdy, potępiające przeciwieństwa prawdy, a więc nie tylko jawny fałsz, lecz także wszelkie półprawdy ${ }^{78}$, obecne są $\mathrm{w}$ przestrzeni, która pozostaje $\mathrm{z}$ gruntu nieetyczna i fałszywa. Biorąc pod uwagę zarówno autorytatywną pozycję akademii, jak i jej nową funkcję w postaci nadawania wiarygodności danemu wycinkowi rzeczywistości cyfrowej ${ }^{79}$, nie można wykluczyć, że uniwersytety funkcjonujące w social media nadają wiarygodności rzeczonemu wycinkowi rzeczywistości lub całemu medium, jakim jest SNS. Powyższe skutki prowadzą do sprzeczności z misją uniwersytetu, który jako ostoja prawdy, dobra, piękna i wolności powinien w jasny sposób przeciwstawiać się fasadowości mediów społecznościowych i edukować społeczeństwo na temat płynących z nich zagrożeń.

Być może problematyka ta, znana niewielkiej grupie nauczycieli akademickich, nie jest jeszcze rozpowszechniona na szczeblu instytucjonalnym. Portale

${ }^{76}$ Akademicki kodeks wartości przyjęty na posiedzeniu Senatu Uniwersytetu Jagiellońskiego w dniu 25 czerwca 2003 r., UJ 2003, https://www.uj.edu.pl/documents/10172/84597185/akademicki-kodeks-wartosci.pdf/ (dostęp: 3.07.2018).

77 C. Fuchs, Social Software and Web 2.0..., dz. cyt., s. 768.

${ }_{78}$ Akademicki kodeks wartości..., dz. cyt.

79 A. Kobylarek, Uniwersytet w komunikacyjnej sieci..., dz. cyt., s. 81. 
społecznościowe wykorzystywane są przez akademie także jako element pewnej strategii, której celem jest dotarcie do odbiorców, budowanie wizerunku czy promowanie własnej oferty. Biorąc pod uwagę znaczący konflikt na poziomie aksjologicznym pomiędzy uniwersytetami a social media, sprzeczności te nie mogą pozostać zignorowane i wymagają przeprowadzenia pogłębionych badań.

\section{Konkluzje}

Liczba użytkowników portali społecznościowych rośnie i na razie nic (nawet skandal z udziałem Facebooka i Cambridge Analytica) nie wskazuje na to, że tendencja ta miałaby ulec zmianie. W pierwszym kwartale 2018 roku na samym portalu społecznościowym Facebook zarejestrowanych było 2,2 miliarda aktywnych użytkowników, co stanowi 13-procentowy wzrost w stosunku do analogicznego okresu w poprzednim roku ${ }^{80}$. Ze względu na swoje funkcje, wielkość i siłę portale społecznościowe stały się immanentnym elementem codzienności nie tylko pojedynczych jednostek, lecz także całych organizacji. Social media gromadzą bowiem ogromne, niedostępne nigdy wcześniej potencjalne audytoria, z którymi w szybki i efektywny sposób można się komunikować, także w znaczeniu marketingowym.

Nie dziwi więc aktywność na portalach społecznościowych jednostek szkolnictwa wyższego. Postępujące urynkowienie sektora publicznego sprawia, że uniwersytety w celu zachowania swojej autorytatywnej pozycji przynajmniej w częściowy sposób muszą reagować na oczekiwania i presje otoczenia. Jednocześnie uniwersytety kierując się doraźnymi korzyściami, nie powinny tracić z pola widzenia prawdziwego oblicza SNS. Aczkolwiek trudno sobie obecnie wyobrazić, by akademie na masową skalę dołączały do akcji \#DeleteFacebook i edukowały społeczeństwo na temat kłamliwej fasady SNS. Konflikt wartości rozgrywający się między współczesnymi uniwersytetami a mediami społecznościowymi, a w konsekwencji potrzeba aktualizacji stanowiska akademii są zagadnieniami nierozpoznanymi i wymagają dalszych badań.

\section{Bibliografia}

Akademicki kodeks wartości przyjęty na posiedzeniu Senatu Uniwersytetu Jagiellońskiego w dniu 25 czerwca 2003 r., https://www.uj.edu.pl/documents/10172/84597185/akademicki-kodeks-wartosci.pdf/3bff64b6-8507-410c-82c5-264a10f3841a (dostęp: 3.07.2018).

Aleksandrowicz T., Relacje uniwersytetu i społeczności lokalnych $w$ mediach społecznościowych. Analiza stron profilowych $w$ serwisie Facebook dla pięciu największych polskich

${ }^{80}$ Facebook Inc., Company Info. Facebook Newsroom, 2018, https://newsroom.fb.com/company-info/ (dostęp: 3.07.2018). 
uniwersytetów w 2014 roku, [w:] T. Wawak, J.F. Jacko (red.), W poszukiwaniu uniwersytetu idealnego, Wydawnictwo Uniwersytetu Jagiellońskiego, Kraków 2016.

Batko R., Liquid University, [w:] J. Kociatkiewicz, M. Kostera (red.), Liquid Organization: Zygmunt Bauman and Organization Theory (s. 104-119), Routledge, London-New York 2014.

boyd d., Social Media: A Phenomenon to Be Analyzed, „Social Media + Society” 2015, t. 1, nr 1, s. 1-2, https://doi.org/10.1177/2056305115580148 (dostęp: 3.07.2018).

Chmielecka E., Kilka uwag o etosie i kodeksach akademickich oraz o odpowiedzialności uczelni, [w:] K. Leja (red.), Społeczna odpowiedzialność uczelni, Wydział Zarządzania i Ekonomii Politechniki Gdańskiej i Instytutu Społeczeństwa Wiedzy, Gdańsk 2008.

Facebook Inc., Company Info. Facebook Newsroom, https://newsroom.fb.com/company-info/ (dostęp: 3.07.2018).

Folga R., Perspektywy i wyzwania marketingu w administracji publicznej w Polsce, „Studia Ekonomiczne" 2014, nr 194: Perspektywy rozwoju marketingu, s. 79-104.

Fuchs C., Social Media: A Critical Introduction, SAGE Publications, Los Angeles-London 2014.

Fuchs C., Social Software and Web 2.0: Their Sociological Foundations and Implications, [w:] S. Murugesan (red.), Handbook of Research on Web 2.0, 3.0, and X.0: Technologies, Business and Social Applications, IGI Global, Hershey-New York 2010, http://fuchs.uti.at/wp-content/uploads/2009/12/Web2.pdf (dostęp: 3.07.2018).

Fundacja Rektorów Polskich i Konferencja Rektorów Akademickich Szkół Polskich, Dobre praktyki w szkołach wyższych: kodeks opracowany przez Fundację Rektorów Polskich, uchwalony przez Zgromadzenie Plenarne Konferencji Rektorów Akademickich Szkół Polskich 26 kwietnia 2007, Fundacja dla Uniwersytetu Jagiellońskiego, Kraków 2007.

Goban-Klas T., Uniwersytet $w$ kontekście nowych mediów i technologii informacyjnych, [w:] P. Sztompka, K. Matuszek (red.), Idea uniwersytetu. Reaktywacja, Wydawnictwo Uniwersytetu Jagiellońskiego, Kraków 2014.

Hausner J., Zarządzanie publiczne, Wydawnictwo Naukowe Scholar, Warszawa 2008.

Kaplan A.M., Haenlein M., Users of the World, Unite! The Challenges and Opportunities of Social Media, „Business Horizons” 2010, t. 53, nr 1, s. 59-68, https://doi.org/10.1016/j.bushor.2009.09.003 (dostęp: 3.07.2018).

Knoch K., Zastosowanie Facebooka w pracy ze studentami. Refleksje dotyczące wykorzystania serwisu w praktyce dydaktycznej, „Zarządzanie Mediami” 2017, t. 4, nr 4, s. 267-277, https://doi.org/10.4467/23540214ZM.16.015.6529 (dostęp: 3.07.2018).

Kobylarek A., Uniwersytet w komunikacyjnej sieci, [w:] A. Kobylarek, J. Semków (red.), Edukacja uniwersytecka $w$ warunkach zmiany kulturowej, Oficyna Wydawnicza Atut, Wroclaw 2008.

Kobylarek A., Uniwersytet wobec konieczności paradygmatycznej zmiany, Agencja Wydawnicza ARGI, Wrocław 2016.

Kostera M., Archetypy, opowieści archetypiczne i metafory, [w:] M. Kostera, B. Glinka (red.), Nowe kierunki w organizacji i zarządzaniu. Organizacje, konteksty, procesy zarządzania, Wolters Kluwer Polska, Warszawa 2012.

Kostera M., Śliwa M., Zarządzanie w XXI wieku. Jakość, twórczość, kultura, Wolters Kluwer Polska, Warszawa 2012.

Krajewska A., Wyzwania wobec uniwersytetu XXI wieku, [w:] A. Ładyżyński, J. Raińczuk (red.), Uniwersytet - między tradycją a wyzwaniami współczesności, Wydawnictwo Impuls, Kraków 2003.

Kreft J., Za fasada społeczności. Elementy zarządzania nowymi mediami, Wydawnictwo Uniwersytetu Jagiellońskiego, Kraków 2015.

Kwiek M., Transformacje uniwersytetu. Zmiany instytucjonalne i ewolucje polityki edukacyjnej w Europie, Wydawnictwo Naukowe UAM, Poznań 2010. 
Leja K., Uniwersytet na rozdrożu, „Studia i Prace Kolegium Zarządzania i Finansów. Szkoła Główna Handlowa” 2017, nr 155, s. 9-24.

Leja K., Zarządzanie uczelnia: koncepcje i współczesne wyzwania, Wolters Kluwer Polska, Warszawa 2013.

Ławicka M., Społeczna odpowiedzialność uczelni wyższej w Polsce, „Zeszyty Naukowe Wyższej Szkoły Humanitas. Zarządzanie” 2016, nr 3, s. 207-220, https://doi.org/ 10.5604/18998658.1228272 (dostęp: 3.07.2018).

Maciąg R., Pragmatyka Internetu. Web 2.0 jako środowisko, Wydawnictwo Uniwersytetu Jagiellońskiego, Kraków 2013.

Marek S., Elementy nauki o przedsiębiorstwie, Economicus, Warszawa 2008.

Pabian A., Marketing szkoły wyższej, Oficyna Wydawnicza ASPRA-JR, Warszawa 2005.

Sarowski Ł., Od Internetu Web 1.0 do Internetu Web 4.0 - ewolucja form przestrzeni komunikacyjnych w globalnej sieci, „Rozprawy Społeczne” 2017, t. 11, nr 1, s. 32-39.

Siemieniecki B., Uniwersytet $w$ świecie mediów i technologii informacyjnej, [w:] P. Sztompka, K. Matuszek (red.), Idea uniwersytetu. Reaktywacja, Wydawnictwo Uniwersytetu Jagiellońskiego, Kraków 2014.

Sowa K.Z., Społeczne funkcje szkolnictwa i elitotwórcza rola uniwersytetu. Uwagi socjologa, [w:] K. Leja (red.), Społeczna odpowiedzialność uczelni, Wydział Zarządzania i Ekonomii Politechniki Gdańskiej i Instytutu Społeczeństwa Wiedzy, Gdańsk 2008.

Stróżewski W., W kręgu wartości, Wydawnictwo Znak, Kraków 1992.

Szeremet P., Zastosowanie marketingu społecznego w realizacji zadań własnych administracji samorządu gminnego, „Zeszyty Naukowe Uniwersytetu Szczecińskiego. Problemy Zarządzania, Finansów i Marketingu" 2012, nr 27, s. 345-353.

Sztompka P., Uniwersytet współczesny; zderzenie dwóch kultur, „Nauka” 2014, nr 1, http://yadda.icm.edu.pl/yadda/element/bwmeta1.element.pan-n-yid-2014-iid-1-art-000000000001 (dostęp: 3.07.2018).

Twardowski K., O dostojeństwie Uniwersytetu, Uniwersytet Poznański, Poznań 1933.

Ustawa z dnia 27 lipca 2005 r. - Prawo o szkolnictwie wyższym (Dz.U. 2017 nr 2183, t.j. z późn. zm.).

Van Dijck J., The Culture of Connectivity: A Critical History of Social Media, Oxford University Press, Oxford 2013.

Wissema J.G., Uniwersytet trzeciej generacji. Uczelnia XXI wieku, Wydawnictwo Zante, Zębice 2009.

Woźnicki J., Uczelnie akademickie jako instytucje życia publicznego, Fundacja Rektorów Polskich, Warszawa 2007.

Ziejka F., Czy można dziś jeszcze mówić o dostojeństwie uniwersytetu?, [w:] P. Sztompka, K. Matuszek (red.), Idea uniwersytetu. Reaktywacja, Wydawnictwo Uniwersytetu Jagiellońskiego, Kraków 2014.

Zuziak W., O powinnościach uniwersytetu, [w:] P. Sztompka, K. Matuszek (red.), Idea uniwersytetu. Reaktywacja, Wydawnictwo Uniwersytetu Jagiellońskiego, Kraków 2014. 